\title{
UMA POETISA BRASILEIRA
}

\section{(1711 ou 1712-1793)}

Se de certo modo, como vimos em outro passo (1), se pode contestar a autoria do "Primeiro Romance Brasileiro", atribuído a D. Teresa Margarida da Silva e Orta, o mesmo não sucede quanto ao poema que Inocêncio viu manuscrito na coleção pertencente a Francisco de Paula Ferreira da Costa, o qual se intitulava:

“Teresa Margarida dá Silva e Orta, encerrada no Mosteiro de Fer"reira, encaminha aos Céus os seus justíssimos prantos no seguinte "poema épico-trágico".

"Dividia-se em cinco "prantos" contendo ao todo cento e noventa "oitavas ritmadas. Do seu contexto (diz Inocêncio), concluía-se apenas "que a autora existia ao tempo da sua composição, reclusa, havia seis "anos; que era viúva e tinha um filho; porém, mal podia pcrceber-se "quais as culpas que lhe imputavam ou que serviam de fundamento pa"ra a persfguição misteriosa de que se queixa. Copiei dêle (diz ainda "Inocêncio), as duas primeiras oiłavas do estilo e linguagem da autora, "visto haver quase a certeza de que tal obra não chegara a ver a luz do "impressão" (2):

$$
\text { I }
$$

Portentos e valor, e mil proesas Descreva o Grego, cante o Mantuano; De seus heróis as cívicas emprêsas Digam outros em metro soberano; Ociosos repitam as finesas Dêsse vendado deus, Amor insano, Entusiasmo Apolo lhes inspire, Todo o Farnaso a seu favor conspire.

\section{II}

"Com rouca voz e lira dissonante Meus males contarei; que injusto fado Contra mim suscitou com mão possante Empenho vil, rigor precipitado! Da fortuna mortal, sempre inconstante, Darei um exemplar, nunca cantado; Pois que a da casa, honra e liberdade Me usurpou a maior fatalidade".

(1). - Anais das Bibliotecas e Arquivos, 1941, vol. XVI, n.0 61 e 62, pgs. 27 a 32 . (2). - Inocêncio, Dicionário Bibliográfico Português, vol. 7. pg. 318 . 


\section{Antônio da Costa no seu livro póstumo "A Mulher em Por- tugal" diz:}

"Esste poema confirma a existência de um mistério. Infelizmente “as circunstâncias do momento parece não terem permitido à autora des"cerrar, de todo, o céu do seu segrêdo. Inocêncio viu o poema que per"tencia ao colecionador Francisco de Paula Ferreira da Costa. Revelava "ser viúva a infeliz poetisa, ter um filho, e achar-se encerrada havia "seis anos no referido convento.

"Qual o motivo da nefanda perseguição? Daquele encêrro for"çado?..." (3).

Ora, a verdade, é que dos 12 filhos que D. Teresa Margarida teve de seu marido, o último, Agostinho Jansen Moler e Pamplona, em 1770, atingira a idade de 22 anos, e como para tantos outros da mesma idade, o frequientar o mosteiro, o claustro, a portaria, o locutório e a grade constituia a satisfação máxima naquela época. Ao mesmo tempo no Mosteiro da Encarnação, das Comendadeiras de Aviz, fundado pela infanta $D$. Maria, filha de $D$. Manuel (que por certo não diferia dos outros conventos, nem a grade e a portaria seriam menos concorridos) achava-se recolhida D. Teresa José Xavier da Cunha e Melo, filha legitima da Casa de Melo, uma das mais ilustres do Reino.

Irmã de Estêvão Soares de Melo Sousa e Lacerda Tavares Godinho, senhor de Melo, eram ambos filhos de Luiz de Melo de Sousa e Lacerda, senhor de Melo, e sua mulher D. Juliana de Meneses e Cunha. Por morte de seu marido casava esta senhora em segundas núpcias com Bernardo de Roxas de Carvalho e Lemos, senhor da Trofa, perdendo por êsse casamento a tutela de seus filhcs e passava a mesma, sendo êles de tenra idade, para seu tio João Manuel de Melo, o qual, ausentando-se para a Vila Boa de Goiaz, no Brasil, encarregado dessa capitania, aí faleceu. Nesta conformidade ficou exercendo as vêzes de tutor.o outro tio, Henrique de Melo de Sousa e Lacerda, o qual, vivendo na província do Alentejo, levou para a sua companhia o sobrinho Estêvão de Melo, no intuito de the reprimir os vícios, a vida dissoluta, o abuso do alcool, que o tornava incorrigível, e que já a mãe, no mesmo intuito, havì feito recolher ao "presídio de uma das tôrres", na própria espressão materna.

A irmã, D. Teresa de Melo, deixara-a o novo tutor recolhida no Convento da Encarnação, a fim de se educar e doutrinar, como a tantas era hábito fazer neste tempo.

Ali a teria conhecido Agostinho Jansen Moler e Pamplona, o filho de Teresa Margarida, e dela se teria agradado, dando-se

(3) - A Mulher em Portugal. Obra póstuma, publicada em benefício de uma criança, 1892. Lisboa, Tip. da Companhia Nacional Editóra, in-8, com o retr. do A., pgs. 68-69. 
início ao romance de amor entre ambos, não obstante a oposição por parte do tio e tutor dela, Henrique de Melo, "em razão da desigualdade entre uma e outra família".

Nem por isso desistiram ou arrefeceram no propósito de se matrimoniaram, se por ventura até não lhes acirrou os intuitos; e D. Teresa de Melo, utilizando os mesmos meios de que 40 anos atrás Teresa Margarida se servira para quebrar a resistência paterna, tentava "persuadir que era necessário o seu casamento" com Agostinho Jansen Moler e Pamplona.

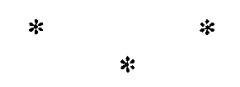

No seu amor pelo filho, no desêjo de o auxiliar, e porventura pela satisfação que the proporcionava o casamento com a descendente legítima de uma das mais ilustres casas do Reino, Teresa Margarida, utilizando tôda a sua influência no Paço, entregava ao Rei e ao Conde de Oeiras, "certa que continha a mais pura verdade... ou um ou dois papéis de D. Teresa de Melo", procurando fazer acreditar a necessidade e urgência de semelhante enlace.

Não eram, porém, os tempos os mesmos; não dispunha Teresa Margarida das influências do sogro, o desembargador Henrique Jansen Moler, nem dos conhecimentos e habilidades dêste, que soubera arrancá-la, a ela, à casa paterna para o casamento urgente, como fôra o seu. Diogo de Mendonça Côrte-Real, o Cardeal da Mota, Antônio Guedes Pereira, Alexandre de Gusmão e o próprio $\mathrm{D}$. João $\mathrm{V}$ haviam falecido há muito, de modo que era difícil fazer agora vingar êsse projeto de casamento por meio de mentiras e fingimentos.

Ao contrário, Henrique de Melo não só dispunha de influências poderosas junto do futuro Marquês de Pombal, de quem era familiar e parente, mas também, encobrindo interêsses inconfessados que defendia, exagerava os erros dos sobrinhos, deformava a verdade dos fatos e informava mal o Ministro.

Teresa Margarida de tudo se apercebia e avaliava os perigos eminentes que corria; não como ela própria dizia, "porque a culpa a fizesse tímida, (mas) sim pelo crédito que tem um parente do Senhor Conde, a quem devem boa amizade os meus inimigos domésticos".

A carta que a seguir transcrevemos, na íntegra, e que se guarda na Bibliotéca Pública de Evora, dirigia a D. Frei Manuel do $\mathrm{Ce}-$ náculo, bem mostra a consternação em que Teresa Margarida se encontrava em mais êste amargo transe da sua vida. Diz assim:

"Excelentíssimo e Revєrendíssino Senhor. Busquei a Vossa Excelên"cia no Paço, quando já se havia retirado e vou por êsse modo à sua "presença, valendo-me da sua piedade para sossêgo da aflição em qua "me vejo. Queira Vossa Exc:lência patrocinar-me para com o Senhor 
"Conde de Oeiras, certificando-lhe que dera um ou dois papéis de $D$. "Teresa de Melo a El-Rei e a Sua Excelência, na certeza que conti"nham a mais pura verdade, parecendo-me moralmente impossível o "fingimento que se diz; pois єu me havia procurado certificar, não só "examinando pessoas familiares da mesma senhora, como ponderando"Jhe os perigos que ameaçava o mentir ao Rei, e nas respostas mos"trarei a minha defesa. Também peço a Vossa Excelência que do mo"do possivel me livre de se aproveitarem desta ocasião os meus inimi"gos, que procurarāo fazer-me algum delito para acabarem comigo, "pelo que espcro de Vōssa Excelência o ser ouvida de alguma acusa"ção, para que não tome corpo mais o ódio que a justiça; e não entenda "Vossa Excelência que a culpa me faça tímida, sim o crédito que tem "um parente do Senhor Conde, a quem dev.m boa amizade os meus "inimigos domésticos. Eu não sei, Excelentíssimo Senhor, fụltar ao "verdadeiro; sei amar a honra, respeitar o Soberano e abominar enga"nos; e tudo se fará evidente, quando se examine qual é a minha con"duta. Domingo farei por mostrar a Vossa Exicelência os papéis em que "se vê que eu fui a mais enganada. Vossa Excclência queira valer à "inexplicável aflição com qu? sin'o que se possa julgar manchada a mi"nha verdade e que eu concorreria para um vilíssimo cngano; livre-me "Vossa Excelência do susto que pideço, e queira honrar as minhas "obediências com as suas ordens, para desamparo das inúmeras obriga"ções. D: us guarde a Vossa Excelência muitos anos.

"Excelentíssimo Senhor Dom Frei Mamuel do Cenáculo. De Vossa

"Excclència mais fiel e mais obragida veneração $D$. Teresa Margarida "da Silva e Orta" (4).

Por outro lado, nem a índole nem os maus hábitos de Eミtêvão Soares de Melo se modificaram; e Henrique de Melo de Sousa Lacerda, escondendo os projetos ambiciosos de se apropriar dos bens dos sobrinhos, alegava, junto de Pombal, essa incorrigibilidade e, quantc à sobrinha, os seus amores com Agostinho Jansen, a sua insubmissão e o mau comportamento que lhe imputava.

Conseguia assim que, por aviso do Secretário de Estado dos Negócios do Reino, o dito Estêvão Soares de Melo recolhesse ao segrêdo da Cadeia da Côrte e sua irmã fôsse mandada para o Cunvento de Portalegre e depois para o de Cós. E obtinha ainda, por alvará de 25 de agôsto de 1770, que ambos fôssem "desnaturalizados da família a que pertenciam, declarados por estranhos dela para todo o efeito, assim de fato como de direito, e mandando passar a sobredita casa, com todos os bens e ações a ela pertencentes, como se mortos fôssem", a Henrique de Melo.

Eis, na íntegra os têrmos do reterido alvará:

"Eu, El-Rej, faço saber aos que êste Alvará virem:

"Qur sendo a Casa dos Donatários de Melo uma das mais antigas "dêstes Reinos e, por isso, maiores as obrigaçōes de conservarem os "descendentes dela a honra e nobreza da memória dos seus ant.passa"dos, a qual não pode ser reprssentada por pessoas indignas que, envi"lecendo e injuriando, por fatos torpes, sórdidos e abjetos, o nascimento "que tiverem, se desherdam por êles da representação dos seus proge- 
"nitores, degradando-se ao mesmo tempo de tôdas as graças e privilè"gios, com que as Leis permitem as instituiçóes e sucessões dos morga"dos, para o esplendor, conservação e aumento da mesma nobreza e "serviço da Corôa; e de nenhuma sorte para patrimônio de indignos, os "quais, com as suas reprovadas açốes, se impossibilitam para servirem o "seu Rei. Havendo sido plenamente provado na minha Real presença, "que a êste infeliz estado se chama incorrigivelmente reduzidos Estêvão "Soares de Melo e sua irmã Dona Teresa de Melo. E porque nestes tèr"mos ficaram cessando, a respeito de ambos os sobreditos, as causas "intrínsecas, e políticas, com que as Leis devolven as sucessões dos vín"culos nas famílias distintas: Ordeno que o dito Estêvão Soares de Melo "e a dita Dona Teresa de Melo, desde a da'a dêste em diante, fiquem "(assim êles, como os seus descendentes, nos casos de os terem) de to"dos e quaisquer bens de Corôa e Ordens, a que aliás pudessem ter qual"quer direito ou ação, e fiquem desnaturalizados da família, a que antes "pertenceram e tanto injuriaram, para serem daqui $\mathrm{cm}$ diante tidos, ha"vidos e reputados por estranhos dela para todos os efeitos de Feito e "de Direito. Assim o mando e determino defin'ivamente de meu motu "próprio, certa ciência, poder real, pleno e supremo, para que mais não "possa vir em dúvida, ou questão em juízo ou fora dêle, s:m embargo "de quaisquer Leis, ou Disposições contrárias, as quais tôdas hei por der"rogadas, como se de cada uma delas fizesse especial menção, não obs“tante a Ordenação, que o contrário determina. E porque não é da mi"nha real, e benigna intenção que a sobredita Casa de Melo se acabe: "Mando que, por efeito dêste, como se os sobreditos mortos fôssem passe "logo con todo o domínio e posse de todos os bens da Corôa, Ordens, e "Patrimoniais de qualquer na"ureza que sejam, e com tôdas as ações a "ela pertencentes, ao imediato sucessor Henrique de Molo de Sousa e "Lacerda, que, imitando àquêles de que descende, se acha louvàvelmente "empregado no meu Real serviço.

"Pelo que: mando à Mesa do Desembargo do Paço, que sendo-lhe "êste apresentado, depois de passar pela Chancelaria, o faça cumprir e "executar com tôdas as ordens necessárias. Dado no Palácio de Nossa "Senhora da Ajuda cm vinte e cinco de agôsto de mil seteçntos e se"tenta, Rei. Conde de Ociras - Alvará por que Vossa Majestade é ser"vido ordenar que Estêvão Soares de Melo e sua irmão Dona Teresa de "Melo sejam privados por indignos de todos os bens da Corôa, Ordens "e Pa'rimoniais, de qualquer natureza que sejam: que fiquem desnatura"lizados da família, a que até agora pertencram: e que todos os refe"ridos bens, passem ao imediato sucessor Henrique de Melo de Sousa "e Lacerda, como se os sobreditos mortos fôssem: tudo na forma acima "declarada. Para Vossa Maiestade ver. João Baptista d" Araujo o fêz. "Registrado na S`cretaria de Estado dos Negócios do Reino no Livro "II das Cartas. Alvarás e Patentes, a fol. 140 verso. Nossa Senhora da "Ajuda a 26 (?) de agôsto de 1770 . João Pacheco Pereira. Foi publicado "êste Alvará na Chancelaria Mór da Côrte e Reino. Lisboa, 31 de agôsto “de 1770. D. Sebastião Maldonado. Registrado na Chancelaria Mór "da Córte e Reino. no Livro das Lejs, a fol. 13 verso. Lisboa, 31 de "agôsto de 1770, Antônio José de Moura" (5).
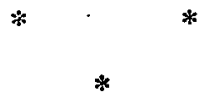

(5). - Coleçãō de Leis, 1770. Na Rógia Oficina Tipográfica, vol. $\Pi$. 
Não se limitou, porém, a violência do Alvará de 25 de agôsto, que acabamos de transcrever na íntegra, a considerar as vítimas "como se mortas fôssem" e a despojá-las de todos os seus bens, "assim de fato como de direito", e mandá-los entregar "ao imediato sucessor Henrique de Melo de Sousa e Lacerda", que, "se acha louvàvelmente empregado no meu Real Serviço" (como dizia o Alvará); mas ainda em 16 de junho de 1772, Martinho de Melo e Castro, pela Secretaria de Estado dos Negócios da Marinha e Domínios Ultramarinos, expedia ao governador de Angola, D. Antônio de Lancastre, o seguinte aviso:

"Pelas Relações juntas assinadas por João Gomes de Araújo, que "serve de Oficial Maior da Secretaria dos Negócios da Marinha e Do"mínios Ultramarinos, será presente a Vossa Senhoria assim os volun"tários, que embarcam na presente ocasião para essa Capitania, com os "Presos de Levas e Soldados, e os que por ordem de Sua Maj:stade vão "degredados para êsse Reino, para que Vossa Senhoria, à vista delas, "lhes possa dar o destino que lhe parecer mais próprio para o s.rviço

"dêsse Reino..."

E juntava a referida "Relação dos Presos, que vão degredados para o Reino de Anǵola até nova ordem de Sua Majestade" (6), entre os quais se encontravam os nomes de Estêvão Soares de Melo e Agostinho Jansen Moler.

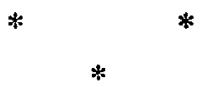

Nem a carta de Teresa Margarida a D. Frei Manuel do Conáculo, nem a influência dêste junto do Conde de Oeiras, nem as razões e papéis em que Teresa Margarida dizia provarem ter sido ela "a mais enganada", conseguiram desfazer a acusação que sôbre ela pendia, de ter mentido ao Rei e de ter concorrido para o " $v i$ líssimo engano" querendo persuadir da necessidade e urgência do casamento de D. Teresa de Melo com o filho, Agostinho Jansen Moler e Pamplona. De nada serviram protestos e diligências, visto Teresa Margarida ter sido encarcerada no Convento de Ferreira de Alves - segundo a tradição e as próprias declarações - nem os esclarecimentos ministrados por ela própria acêrca dos motivos da sua prisão, como vamos vêr.

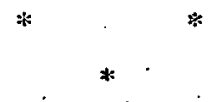

Em 1889, mais de um século decorrido sôbre êstes acontecimentos, D. Antônio da Costa "no intuito de descobrir o ponto ca- 
pital dêste mistério, depois de empregar tôdas as diligências, de cosultar as crônicas e investigar o inédito Dicionário de Luiz Cardoso", escrevia à última freira do Convento de Ferreira de fives, D. Josefa Emília de Costa Machado solicitando os informes que por ventura tivesse acêrca do assunto. Esta, em 25 de agôsto de 1889 , respondia o seguinte:

"A respeito das informações da tal senhora achei o seguinte, por "tradição: que a senhora, de que se trata, veio para aqui por ordem do "Marquês de Pombal, como prisioneira; até o que a acompanhou entrou "dentro para escolher uma cela que servisse de cárcere e não via sol " $n: m$ lua. Quanto ao motivo porque a meteram aqui, não se sabe; sa"be-se só que ela era muito boa senhora, de muito talento, e muito "instruida".

"Há aqui uma novena do Patriarca S. Bento, que ela fêz e ofereceu “às religiosas. E' muito bem feita e no princípio diz alguma cousa re"lativa à tragédia que estava sofrendo" (7).

Foi, portanto, aí nessa cela que lhe servia de cárcere, no Convento de Ferreira de Aves, onde "não via sol nem lua" que 'Teresa Margarida escreveu, entre "prantos", êsse poema que Inocêncio viu manuscrito na coleção pertencente a Francisco de Paula ferreira da Costa. Foi, pois, também aí, que Teresa Margarida escreveu essa "Novena do Patriarca S. Bento" que ofereceu as : eligiosas e dedicou à abadessa do mosteiro, $\mathrm{D}$. Ana Josefa de CasteloBranco, em carta que $\mathrm{D}$. Antônio da Costa obteve da citada $\mathrm{D}$. Josefa Emília da Costa Machado, última freira do mesmo mosteiro, cujo teor é o seguinte:

"Sôbre os seus al ares (de S. Bento) tem corrido o meu pranto. "Ele sabe que $p \leqslant l o s$ di'ames da razão foram sempre dirigidas as minhas "açōes; que a honra, o decôro e o pundonor foram sempre inseparáveis "do seu coração, que é mais pronto a padecer enganos que admitir infa-

"mes indústrias, por serem sempre honrados os seus sentimentos... Em "face do céu e da terra estão justificadas as obrigações com que nasci “e não posso deixar de dizer que 0 vosso santo Patriarca parice de "jus'iça rigorosa obrigado a socorrer-se; pois não ignora que eu não "segui indiscretas insinuaçōes, pelos vínculos da natureza. Ele desprezou “as elevaçōes do trono, conhecendo que é maior grandeza pisá-lo, que "subir a êle; e eu, infeliz̄, sem o seu grande espírito, sempre segui que "para os lustres de alheias fidalguias não devia incomodar-me, havendo "nascido de ilustres, e que pela esperança de possuir não é sujeito a "desacerto quem nasceu entre tesouros e nunca sentiu indigência... De "vossa senhoria, cativa, a mais fiel e obrigada - Dorotéia Engrássia Ta"vareda d'Almira" (8).

Não está completo êsse documento. Há mais reticêncizs, quie representam, possivelmente, cortes e omissões. Nem po- isso dt ixa de ser. documento valiosíssimo, já porque por êle se "prova set de

(7). - D. Antônio da Costa, obra cit., pgs. 69-70

(8). - D. Antônio da Costa. Ob. cit., pgs. 7 p.71. 
D. Teresa Margarida o anagrama de Dorotéia Engrássia, que a própria $D$. Teresa se assinou com êle" na transcrita carta que dirigiu "à abadessa, quando já encerrada no Mosteiro de Ferreita", já pelas referências aos acontecimentos em que até utiliza ás mesmas palavras de que se servira na carta a Cenáculo, dizendo ser o seu coração "mais pronto a padecer enganos, que admiťir infames indústriais", alusão claríssima à culpa que lhe imputavam (ra tentativa de fazer acreditar na necessidade e urgência do casamento de $\mathrm{D}$. Teresa de Melo com o filho) de ter mentido ao Rei e ao Ministro.

$\mathrm{E}$, finalmente, alude, com transparente despeito ao fato de the terem atribuído o desêjo da união do filho com D. Teresa de Melo. por ser esta herdeira de uma das casas mais nobres do Reinc, quando diz: "sempre segui que para os lustres de alheias fidalguias não devia incomodar-me havendo nascido de ilustres, e que pela esperança de possuir não é sujeita a desacertos quem nasceu entre tesouros e nunca sentiu indigência..."

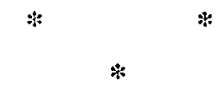

Mas, nem por isso $D$. Antônio da Costa, não obstante ter empregado tôdas as diligências, consultando crônicas e investigando inéditos - como afirma - conseguiu desvendar o mistério; e, indeciso, formula as seguintes hipóteses, interrogando: "Foi um fato político êste, que o Marquês de Pombal quis punir? ou um fato particular, de que recorreram para o seu poder? $\mathrm{E}$, procurando interpretar o teor da carta à abadessa, aventa a idéia de "proposta ou imposição de um casamento de grandes haveres, acompanhado de qualquer indignidade, com pessoa elevada, que o pundonor da noiva devesse repelit, preferindo o seu martírio vitalício à aceitação das "infames indústrias", a que se refere".

E acrescenta:

"Não sei de outra explicação. Crime político, mostra-se que não o "havia. Delito de família? E se o tivesse havido, como é que a sua "viuv€z a não salvaguardava? $\mathrm{E}$ se, como viúva, já não tinha no espôso "um pro'etor; se, por novo ainda, não tinha no filho quem lhe advo"gasse a inocência; como é que a sua honra e a sua liberdade não en"contraram escudo em seu irmão Matias Aires Ramos da Silva de Eça "que, por sua influência na Côrte e por seu elevado cargo de Provedor "da Casa da Moeda, teria de certo fôrça moral para defender o direito "de uma irmã, duas vêzes sagrada para êle? Dar-se-ia o caso... (e per"doe-me a memória dêsse homem, se é falso testemunho) de que a vio-

"lência proviesse de seu mesmo irmão? Se assim era, porque provinha

"dêle? Se não era, porque não protegia a desventurada? 
Ignorou Inocêncio a "histótia" da Freira e D. Antônio da Costa, não obstante tốdas as diligências, não atinou com os verdadeiros motivos porque Teresa Margarida fôra privada de liberdade pelo onipotente Marquês de Pombal. Faltou-lhe a carta escrita a D. Frei Manuel do Cenáculo, em que Teresa Margarida pede o patrocínio dêste junto do "Snt.. Conde de Oeiras, certificando-lhe que dera um ou dois papéis de $D$. Teresa de Melo a: El-Rei e a S. Exa., na certeza que continham a mais pura verdade, parecendo-me moralmente impossivel o fingimento que se diz" (9). Faltou-lhes a súplica de D. Juliana de Meneses e Cunha que adiante transcrevemos.

Não houve, pois, "imposição de um casamento de grandes haveres, acompanhado de qualquer indignidade, com pessoa elevada, que o pundonor da noiva devesse repelir, preferindo o martírio vitalício à aceitação das "infames indústrias" a que se refere", como pensava D. Antônio da Costa. Houve apenas o que o leitor já sabe: a culpa que the imputavam de ter participado no fingimento da urgente necessidade do consórcio de D. Teresa de Melo com o filho, mentindo ao Rei.

Não houve, portanto, nem "crime político", nem "delito de familia"; nem a sua viuvez tinha nada que salvaguardar. Quanto ao marido, falecera havia muito; o filho mais novo fôra deportado para Angola, e os mais velhos encontravam-se dispersos, uns pela Índia e pelo Brasil, outros por vários conventos e mosteiros. O irmão, Matias Aires, morrera em 1763 e o resto dos parentes, os filhos do irmão, êsses eram para ela os "inimigos domésticos", a que aludia na cartá a D. Frei Manuel do Cenáculo.

"A desgraçada não encontroú um braço que se lhe estendesse (diz "ainda D. Antônio da Costa), nem uma instituição que a salvasse; e "neste abandôno, sem luz, sem liberdade, sem marido, sem filho, sem "ninguém, só na vingadora poesia ençontrou uma voz, para lançar a "maldição dos homens peran"e as gerações futuras" (10).

Mas, ainda que assim não fôsse, de nada serviria qualquer tentativa de proteção; pois o que realmente existia era "o crédito que tem um parente do Snt. Conde de Oeiras, a quem devem boa amizade os meus inimigos domésticos". Eram as maquinações de Henrique de Melo de Sousa e Lacerda, eram os parciais dos filhos de Matias Aires, era a vontade absoluta de Pombal e, contra esta näo havia resistência possivel; falhavam tôdas as tentativas, anulavam-se todos os testemunhos, apagavam-se tôdas as razões, diluiam-se tôdas as provas, extinguia-se tôda a justiça, para só triunfar a tirania, a crueldade e a injustiça.

(9). - Doc. cit.

(10). - D. Antônio da Costa, ob. cit., pgs. 72-73. 
Entretanto o Rei era acometido de freqüentes acessos de apoplexia, e em 12 de novembro de 1776 caía sem alento e sem fala. Apenas por escrito exprimia os seus pensamentos e aquiescia a tôdas as solicitações da Regência (11).

Ainda $\mathrm{em}$ vida do monarca, e por ordem da Raínha, soltava-se o bispo de Coimbra, D. Miguel da Anunciação, encerrado no forte das Maias havia 8 anos; mandava-se regressar José de Seabra dos confins da África e, contra a vontade do próprio Marquês de Pombal, pagava-se um milhão de cruzados de dívidas (12).

Em 24 de fevereiro, contando 63 anos de idade e 26 e meio de reinado, finava-se D. José, após 3 longos meses de sofrimento. Em disposição da última vontade recomendava à filha e herdeira do trono o pagamento das dívidas e o indulto aos criminosos de Estado.

Pombal, menosprezado pela Côrte, por aquêles mesmos que outrora, humildes e submissos, se compraziam em servilismos e venerações, insultado e escarnecido pela plebe, via chegada a hora da desdita; e, naufragado o prestígio da sua autoridade, insistia pela demissão. Esta era-lhe finalmente concedida e pouco depois fixava-se-lhe residência em Pombal, donde nãc poderia ausentar-se .

"As prisões abriam-se (diz Lúcio de Azevedo), para trazerem à vida “comum centenas de pessoas, para muitos como ressuscitados, vinham “contar as tristezas do seu encèrro, a brutalidade dos carcereiros e a "Isnta agonia dos que, sem confôrto, quase à míngua, nas lôbregas en"xovias, a morte havia libertado..." (13).

$*$

* *

Como tantos outros, Teresa Margarida beneficiaria do indulto geral e regressava à Côrte, depois de "padecer quase sete anos de degrêdo e cárcere" (14), "reclusa e proíbida de tôda a comunicação" (15). Aí, no Mosteiro de Ferreira, compusera êsse poema épico-trágico, em que encaminhava "aos Céus os seus justíssimos prantos" (16), de que fala Inocêncio. Aí redigira essa famosa novena, em que, à "face do Cêu e da terra, justificava as obrirações com que nasceu...", em "que a honra, o decoro, e o pundonor foram sempre inseparáveis do seu coração..." (17).

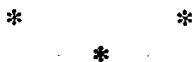

(11). - Lúcio de Azevedo, O Marquês de Pombal e a sua época, pgs. 343 e seguintes.

(12) - Idem, idem.

(13). - Lúcio de Azevedo. Ob. cit., pg. 350

(14): - Tôrre do Tombo - Desembargo do Paço, Maço 1.883 , n. 64.

(15): - Feitos Findos - Letra T., 225, fls. 28 Vol. a 30 vol.

(16). - Inocéncio. Vol. 7 , pg. 317 , já cit

(17). - D. Antônio da Costa. Ob. cit., pg. 70. 
Tinha então 65 anos. Regressava, dizia “... depois de padecer quase sete anos de degrêdo e cárcere...", desmantelada a fazenda, dispersa a casa, "martirizada de trabalhos, e desgostos, sem meios para sustentar a larga, e vagarasa disputa de tantos litígios... desejosa de descanso, para melhor poder tratar da sura salvação e amparar seus filhos" (18). Acolhia-se, por isso, à casa do cunhado, o velho inquisidor Joaquim Jansen Moler.

Ao filho, Agostinho Jansen, desterrado havia tantos anos, como ela, era igualmente concedido indulto e mandado regressar de Angola, por Aviso da Soberana, datado de 25 de abril. A êsse Aviso se refere o seguinte ofício o governador de Angola, D. Antônio de Lancastre, para Martinho de Melo e Castro .

"Ilustríssimo e Excelentíssimo Senhor. Em virtude de Aviso de Sua "Maiestade, expedido por Vossa Excelência em 25 de abril de 1777, con"cedi licença para se embarcar a recolher a êsse Reino, Agostinho Jansen “ Moler, que se achava degredado neste Reino, adonde se achará, se"gundo me persuado. Deus guarde a Vossa Excelência, São Paulo de "Assunção, a 20 do agôsto de 1778. Ilustríssimo Senhor Martinho de "Melo e Castro - D. Antônio de Lancastre" (19).

Por outro lado, D. Juliana de Meneses e Cunha, como tantas vítimas do despotismo de Pombal, recorria à piedade da Raínha, a fim de "se levantar o exterminio a seus filhos" (Estêvão Soares de Melo e D. Teresa de Melo) "e se naturalizarem à sua geração". E fazia-o em documento de tal modo interessante que não hesitamos em transcrevê-lo na íntegra:

"Senhora. Diz. D. Juliana de Meneses e Cunha, casada com Ber"nardo de Roxas de Carvalho e Lemos, Senhor da Trofa, que do pri"meiro matrimônio, que a suplicante contraiu com Luiz de Melo de Sousa "e Lacerda, Senhor de Melo, lhe ficaram dois filhos, Estêvão Soares de "Melo, sucessor da sua casa, e D. Teresa de Melo, os quais com inex"nlicável mágua da suplicante se acham reduzidos a um estado verda"deiramente infeliz e digno da maior compaixão. Porque. sendo ca"Iıniados na Real Presença do Augustíssimo Rei Senhor Dom José, o "Primeiro, glorioso Pai de Vossa Majestade, como delinquientes escan"dalosos e incorrigíveis, foi o mesmo Senhor servido, por Alvará de 25 "de agôsto de 1770 , cuịo exemplar a suplicante oferece, desnaturalizá"los da Família a que pertenciam, declarando-os por estranhos dela para "todos os rfeitos, assim de fato, como de Direito, e mandando passar a "sobredita casa com todos os bens e ações a ela pertencentes, como se os "filhos da suplicante mortos fôssem, a seu tio Henrique de Melo de Suusa “e Lacerda: e por Aviso do Secretário de Estado dos Negócios do Reino. "foi o dito Estêvão Soares de Melo recolhido à prisão de um áspero "segrêdo na Cadeia da Côrte; e daí remetido para o Reino de Angola,

(18). - Tôrre do Tombo - Desembargo do Paço. Doc. cit. Maço 1.883, n.0 64. (19). - Arquivo Histótico Colonial - Maço 63 de Angola - 1778-1779. 
"aonde se tem conservado, apesar das grandes calamidades que tem "sofrido, pois até do socôrro dos alimentos o deixou privado a sua des"graça; e a dita D. Teresa de Melo, por outro semelhante Aviso, foi "mandada para o Conven'o de Portalegre e depois para o de Cós, aonde "se acha $\mathrm{cm}$ igual adversidade".

"Muito tnormes deviam ser os fatos, com que perante a Majestade "do dito Senhor se representou manchado o procedimento de cada um "dos desgraçados filhos da suplicante; pois que em razão dêles se jul"garam merecedores de serem totalmente privados até dos direitos de "sangue e da natureza. Torém, Soberana e Augustíssima Senhora, a "suplicante vencida pelos inextinguíveis afetos de Mãe e.animada pela "Real Benevolència de Vossa Majestade, não pode dispensar-se de re"presentar aos pés do trono, que êste é um dos casos em que com es"càndalo da humanidade se conhece bem quais são os lastimosos efeitos "que é capaz de produzir a calúnja, sendo estimulada pelo ódio e pela “ambição.

"Como a suplicante, em razão do seu segundo casamento, vio na "conformidade das Leis do Reino a perder a tutela dos ditos seus filhos, "passou a mesma, sendo êles de tenra idade, para seu tio João Manuel "de Melo; e, porque êste se ausentou para Vila Boa de Goiaz, encar"regado do Govêrno daquela Capitania, onde faleceu, ficou logo com "procuração sua exercendo às vêzes de tutor o outro tio, Henrique de "Melo, o qual, vivendo na Frovíncia do Alentejo, teve em sua compa"nhia o filho da suplicante.

"Aí the faltou a boa educação, que devia ter, e essa falta foi causa "de se entregar ao uso do vinho com excesso repreensivel. Para lhe "imprimir o devido horror a êste vício, conseguir a sua $€$ menda e acau"telar as desordens, de que podia ser causa, se lembrou a suplicante "de o fazer recolher por Ordem Régia a uma das Tôrres da Barra desta "cidade, aonde se conservou por algum tempo; e quando a suplicante "tratava de lhe pedir nova administração para a sua casa, por conhecer "que lhe não era útil a de seu tio Henrique de Melo, se adiantou êste "a pedir a sua sol'ura; e, posto $\mathrm{cm}$ liberdade, o conduziu na sua com“panhia o dito seu tio para a Praça de Campo Maior, aonde era Co"ronel, para lhe maquinar a sua última ruína; porque, passado muito "tempo, formou dêle a queixa que quis, pela Secretaria de Estado dos "Negócios do Reino, de que $r$ sultou ser preso no Castelo da referida "Praça; e sem que aquêle miserável menor fôsse ouvido, sem se lhe "formar processo, nem se lhe admitir defesa, aparcceu pùblicamente "castigado com a severa pena do referido Alvará, porque a ambiciosa "intuição do tio soube conciliar o favor do Ministro do Estado, que o "introduziu na Real Assinatura, inculcando, como certo e verificado por "provas infalíveis, tudo aquilo que consistia sòmente em uma simples "e cavilosa queixa; e a isto se seguiu ser o filho da suplicante removido "pará a Cadeia do Limoeiro, aonde esteve em apertado segrêdo, e daí "Exterminado para Angola.

"E. como o projeto do tio não podia ficar satisfeito com a ruína "daquele sobrinho, restando-lhe o obstáculo da imediata sua irmã, a "qual se achava recolhida no Mosteiro da Encarnação desta cidade, "era riecessário que também ela experimentasse o mesmo golpe. Mas o "único delito, de que com verdade se the podia fazer carga, consistiu "sòmentc em querér casar com Agostinho Jansen e fazer persuadir que "era necessário, o casamento, sendo para isso iludida pela mãe dêle "D. Teresa Margarida da Silva e Orta, a fim de vencer a repugnância "que encontrava, $\mathrm{em}$ razão da desigualdade entre uma e outra família. "Nas circunstâncias ponderadas, parece que sem receio pode a su"plicante afirmar que o dito Alvará foi subrepticiamente alcançado; pois "que não podia ser conforme à Real, e piedosa intuição de Sua Majes- 
"tade, que está em Glória, que os filhos da suplicante sem culpa formada, "sem provas e sem defesa, fôssem tão àsperamente castigados, perdendo "a nobreza, com que nasceram, e os bens que tinham herdado, não "havendo alguns da Corôa na sua casa, pois todos eram patrimoniais, "em que se incluía a avultada herança de setenta mil cruzados em "dinheiro e vinte em prata, que deixou o dito seu tio João Manuel "de Melo; o que tudo tem metido em si o dito Henrique de Melo de "Sousa e Lacerda.

"E como sem embargo de tudo está a suplicante vendo, sem con"solação, o infeliz abatimento, em que êles se acham, o qual não pode "deixar de refletir também sôbre a suplicante, pois que são pedaços "das suas en'ranhas, e uma semelhante desgraça parece que é objeto "bım digno da real comiseração de Vossa Majestade: Portanto, pede "a Vossa Majestade, que por efeito da sua real clemência seja ser"vida mandar expedir. as ordens necessárias, para que os ditos filho "e filha da suplicante dos degredos em que se acham, se restituam a "esta Côrte na sua liberdade, mas sujeitos à direção da suplicante; ha"vendo por bem declará-los por habilitados para tôdas as honras e "restituidos a todos os direitos do sangue, e da família e à posse dos "seus bens e casa. E. R. M.

Sôbre esta petição mandava a Raínha consultar a Mesa do Desembargo do Paço e ordenava ao Corregedor do Cível da Côrte, que informasse com o seu parecer; ouvindo a parte por precatória e, finalmente, por Alvará de 7 de agôsto de 1777 era revogada a desnaturalização de Estêvão Soares de Melo e sua irmã D. Teresa de Melo, nos têrmos seguintes:

"Eu, a Raínha: Faço saber aos que êste Alvará virem:

"Juliana de Meneses e Cunha, para haverem de ser restituidos seus "filhos, Estêvão Soares de Melo e Dona Teresa de Melo, à família, "honra e bens, de que tinham sido privados, e o que sôbre esta ma"téria, depois de ser a par'e ouvida e tomadas as informaçōes, me "consultou a Mesa do Desembargo do Paço; e, atendendo a que as "desordens e excessos, em que se precipitaram os filhos da suplicante, "sendo cometidos quando tinham poucos anos, e uma notória falta "de educação, que thes convinha, se deve atribuir a inconsideração "e ignorância, e por isso são mais dignos de escusa e de perdão; muito "mais depois que o severo castigo, que têm padecido, e o trabalho e "indecoro; a que êle os sujeitou, os terá conduzido ao arrependimento "e emenda necessária, para que daqui por diante procurem viver da "sorte que conservem o esplendor da sua casa, esperando que sobre"tudo os obrigue a isso a lembrança e reconhecimento da clemência, "que com êles uso e com que atendo a mesma sua casa, e a procurar, "por êste meio, que nela haja sucessores que, imitando os seus maiores, "façam esquecer as culpas e indecências, que deram causa ao Alvará "de vinte e cinco de agôsto de mil setecentos e setenta: Sou servida "revogar o dito Alvará, perdoando tôda a pena, que nele se tinha "determinado contra os ditos Estêvão Soares de Melo e Dona Teresa "de Melo; e mandar que sejam restituídos plenissimamente ao cstado "natural, e civil, em que se achavam ao tempo enl que o dito Alvará "foi promulgado; e outro sim ordeno que, da mesma forma em que "para seu tio Henrique de Melo de Sousa Lacerda passaram em vir"tude do dito Alvará todos os Bens da Casa de seu sobrinho, o referido "Estêvão Soares, agora com onímoda reversão lhe $s \in$ jam logo resti"tuídos, sem embargo do dito Alvará, que em tôdas as suas partes "hei por derrogado, para que em nenhum tempo tenha efeito algum 
"eim juízo, ou fora dêle; e o que neste determino se observará sem "falta alguma, pena do castigo, que fòr servida determinar, e do maior "de todos, que é da minha Real Indignação contra qualquer Pessoa

"de qualquer estado, ou condição, que seja, que se opuser, alegar

"ou contradizer a inteira observância do que neste tenho determinado.

"Pelo que: Mando à Mesa do Desembargo do Paço que, sendo-lhe

"êste apresentado, depois de passar pela Chancelaria, o faça cumprir

"como neles se contém, fazendo expedir as ordens, e despachos ne-

“cessários. Dado no Palácio de Queluz - aos sete dias do mês de

“agôsto dc mil setecentos e setenta e sete. Raínha. Visconde de Vila

"Nova da Cerveira. Alvará porque Vossa Majestade, pelos modívos

"nele declarados, revogando o Alvará de 25 de agôsto de 1770 , é

"servida perdoar tôda a pena, que nele se tinha determinado a Estêvão

"Soares de Melo e a Dona Teresa de Melo, para que sejam restituídos

"plenissimamente ao estado natural e civil.em que se achavam ao

"tempo em que o dito Alvará foi publicado. E que lhes sejam logo

"restituidos os bens de sua casa; tudo na forma acima declarada. Para

"Vossa Májestade vêr. Clemente Isidoro Brandáo o fêz (20).

E, semelhantemente ao que se fizera, a respeito do filho de Teresa Margarida da Silva e Orta, Agostinho Jansen Moler, o Governador de Angola, D. Antônio de Lancastre, enviava a Martinho de Melo e Castro êste ofício:

"Ilustríssimo e Excelen'íssimo Senhor. Em observância dos Avisos "da Raínha Nossa Senhora, expedidos por Vossa Excelência com a "data de $28 \mathrm{~d}$ a agôsto de 1777, mandei pôr na sua inteira liberdade "a Estêvão Soares de Melo, que se achava degredado n.ste Reino, e "lhe concedi licença para se embarcar para Portugal, o que fêz pelo "pôrto da Bahia. Deus guarde a Vossa Excelência. São Paulo de $\Lambda s-$ "sunção, a 20 de agôsto de 1778. Tlustríssimo e Excelentíssimo Senhor "Martinho de Melo e Castro. D. Antônio de Lancastre" (21).

Não obstante a longa ausência de Agostinho Jansen em Angola, nem por isso the arrefeceu os intuitos de se matrimoniar com D. Teresa de Melo, como êle cativa e desterrada no Mosteiro de Cós, nem ela dêle se esquecera, apesar de idênticos trabalhos e sofrimentos. E,

"Aos dezenove dias do mês de janeiro de mil e setec:ntos e "oitenta anos, de tarde, nes"a paroquial igreja de S. Tiago de Lisboa, "em minha presença e das test:munhas abaixo assinadas, se receberam "por marido e mulher, na forma que ordena o Sagrado Concílio Tri"dentino e Constituição dêste Patriarcado, Agostinho Jansen Moler e "Pamplona, soltsiro, filho legítimo de Pedro Jansen Moler, já falecido "e de sua mulher D. Teresa Margarida da Silva e Orta, na'ural e ba"tizado na freguesia de S. Tiago de Lishoa aonde se desobrigou, as duas "quaresmas antecedentes; com D. Teresa José Xavier da Cunha e Me"lo, filha de Luiz de Melo de Scusa e Lacerda e de sua mulher D. "Juliana Luiza de Meneses, ambos d.funtos, natural e batizada na "Vila de Melo, Bispado da Guarda, e de presente recolhida no Mos"teiro da Vila de Cós, aonde se tem desobrigado as quaresmas do es-

(20). - Tôrre do Tombo. Doc. cit

(21). - Arquivo Histórico Colonial. Maço 63 de Angola, 1778-1779. 
“tilo. em virtude de banhos correntes e um despacho de Sua Eminência

"em que lhes dispensa nos banhos da naturalidade da contraente e da

"formalidade de banho do contraente do Reino de Angola, em o qual

"despacho concedeu licença para se receber por procuração que fêz

"ao Excelentíssimo Dom Sebastião Maldonado, cujos papéis ficam em

"seu poder e cartório, sendo testemunhas que de presente estavam; D.

"Pedro Maldonado, morador na Rua Direita dos Anjos e da mesma

"freguesia; Francisco Luciano de Freitas e Esmeraldo, moraldor na

"Rua Direita de S. José, da mesma freguesia, e mais pessoas que pre-

"sentes estavam, que todos disseram serem os contraentes os proprios;

"e o procurador do contraente e as testemunhas comigo assinaram, do

"que fiz êste assento, que assinei dia ut supra. O Prior Antônio José

"Inácio - Dom Sebastião Maldonado, como procurador, Francisco Lu-

“ciano de Freitas Esmeraldo, Dom Pedro Maldonado" (22).

Realizava assim o filho de Teresa Margarida da Silva e Orta, Agostinho Jansen Moler, o sonho supremo da sua existência que os tormentos sem conta possivelmente mais haviam afervorado, matrimoniando-se finalmente "com sua filha legitima da Casa de Melo, uma das mais ilustres do Reino", D. Teresa José Xavier de Cunha e Melo.

Quanto ao irmão de D. Teresa de Melo, Estêvão Soares de Melo, o Snr. de Melo, o companheiro de desdita no desterro de Angola, êsse desposara D. Tomásia Rita de Sousa Lemos e Meneses e em 17 de novembro de 1785 era já falecido, deixando, porém, uma filha menor, Ana Rufina de Melo Sousa Lacerda Tavares Godinho Barros Cardoso.

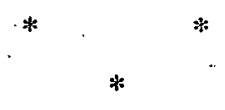

Fica assim desvendado e defintivamente esclarecido o mistério que tantas conjecturas mereceu e tão penosas investigações e buscas custou a D. Antônio da Costa, como êste refere no seu precioso livro póstumo "A Mulher em Portugal". Também ao erudito e douto autor do "Dicionário Bibliográfico Português", Inocêncio Francisco da Silva, mereceu o assunto referência quando afirma "mal podia perceber quais as culpas que the imputavam ou que serviam de fundamento para a perseguição misteriosa de que se queixa" a autora do poema épico-trágico, que êle vira manuscrito na coleção pertencente a Francisco de Paula Ferreira da Costa.

Nem a obra viu a luz da impressão, nem nós, mau grado as diligências, conseguimos vêr o manuscrito donde Inocêncio transcreveu as duas primeiras oitavas, que por assim dizer, são 0 argumento do poema.

(22): - Arquivos Paroquiais. - Dos Casados de 1723 até 1781. - Freguesia do S. Tiago. - L.O 3.0 fol. 40 
Contudo, são elas o bastante para se ajuizar do valor da composição, do estilo e linguagem da autora, que em nada se afasta do valor da maioria das obras poéticas do tempo, em que o assunto era quase sempre o elogio das virtudes do monarca ou a lisonja das qualidades do valido, as perseguiçōes políticas, as injustiças, os abusos de autoridade, os rigores das prisões, as deportações, os maus tratos, e as misérias a que eram submetidos os presos e encarcerados.

O poema épico-trágico de Teresa Margarida não fazia excepção; o seu contexto limita-se à narração dos acontecimentos da sua própria existência, as atribuições do seu viver, o seu casamento contrariado, os doestos paternos, o seu desterro em Agualva, as demandas com 0 irmão, com os sobrinhos, com os familiares, com os credores, as hipotecas, as execuções, os dinheiros adiantados, os empréstimos onerosíssimos, a emprêsa do Maranhão, a doença e a morte do marido, e finalmente a mistificação com que pretendeu iludir o monarca e o ministro, querendo fazer crer na urgência do casamento de Teresa de Melo com o filho, o que valeu a êste a deportação para Angola e a reclusão de Teresa Margarida no Mosteiro de Ferreira de Aves, por ordem de Pombal.

Tudo isto, em parte ou no todo, devia ser o objeto dêste poema épico-trágico a que se refere Inocêncio, cujas atribulações e martírios fazem da sua autora, D. Teresa Margarida da Silva e Orta, uma poetisa brasileira infeliz. 